\title{
PERLINDUNGAN HUKUM TERHADAP MEREK YANG TERDAFTAR
}

\author{
Zaenal Arifin $^{1}$, Muhammad Iqbal ${ }^{2}$ \\ ${ }^{1}$ Magister Hukum, Universitas Semarang, Semarang \\ ${ }^{2}$ Fakultas Ekonomi, Universitas Semarang, Semarang \\ zaenal@usm.ac.id
}

\begin{abstract}
Abstrak
Penelitian ini bertujuan untuk mengkaji dan menganalisa bagaimana perlindungan hukum terhadap merek yang terdaftar dan mengapa perlindungan terhadap merek yang terdaftar dapat berakhir. Merek bagi produsen merupakan citra sekaligus nama baik bagi perusahaan, selain itu juga merupakan bagian dari stategi bisnis. Tidak ada seorang produsen yang tidak menggunakan merek sebagai identitas atas barang yang diproduksinya atau jasa yang diberikan. Identitas yang diwujudkan dalam merek tersebut merupakan pengenal dan sekaligus pembeda antara merek suatu perusahaan tertentu dengan merek perusahaan yang lainnya. Hal ini yang menjadikan sebab mengapa sering terjadi sengketa terhadap merek. Metode penelitian yang digunakan adalah yuridis normatif. Temuan dari hasil penelitian ini bahwa terdaftarnya merek dapat berakhir karena berakhirnya masa berlakunya merek, penghapusan merek karena permintaan sendiri dari pemilik merek, penghapusan merek terdaftar atas prakarsa dari Menteri setelah mendapatkan rekomendasi dari Komisi Banding Merek, dan penghapusan merek karena adanya gugatan dari pihak ketiga. Adanya perlindungan merek dimulai dari pendaftaran merek, perlindungan merek selama masa jangka waktu terdaftarnya merek selama 10 (sepuluh ) tahun dan dapat diperpanjang dengan jangka waktu yang sama, adanya penindakan baik gugatan secara perdata, penuntutan secara pidana maupun langkah administratif berupa penolakan pendaftaran merek dan penghapusan merek.
\end{abstract}

Kata kunci : perlindungan hukum; merek; kekayaan intelektual 


\title{
LEGAL PROTECTION OF REGISTERED BRANDS
}

\author{
Zaenal Arifin', Muhammad Iqbal $^{2}$ \\ $\mathbf{1}_{\text {Master of Law, Semarang University, Semarang }}$ \\ ${ }^{2}$ Faculty of Economics, Semarang University, Semarang \\ zaenal@usm.ac.id
}

\begin{abstract}
This study aims to review and analyze how the legal protection of registered trademarks and also why protection of registered trademarks can end. Trademarks or brand for producers is an image as well as a good name for the company, beside that it is also a part of the business strategy. There is no producer who does not use the brand as an identity for the goods they produced or the services they provided. The identity which is embodied in the mark is an identifier and at the same time becomes a differentiator to the others. This is why disputes often occurs against the brand. The research method uses a normative juridical. the results of this study that the registration of a mark may end due to the expiry of the validity period of the mark, the deletion of the mark due to request of the owner, the deletion of the registered mark at the initiative of the Minister after obtaining a recommendation from the Trademark Appeals Commission, and the deletion of the mark due to a lawsuit from a third party. The existence of trademark protection starts from the registration of the mark, protection of the mark during the period of the registration of the mark for 10 (ten) years and can be extended with the same period of time, there is legal action both in civil lawsuits, criminal prosecution and administrative steps in the form of refusal of trademark registration and deletion of brand.
\end{abstract}

Keywords: legal protection; brand; intellectual property 


\section{PENDAHULUAN}

\section{A. Latar Belakang Masalah}

Pengertian merek sebagai bagian dari Hak Milik Intelektual tidak terlepas dari pemahaman bahwa hak merek diawali dari temuan-temuan dalam bidang Hak Kekayaan Intelektual lainnya, misalnya hak cipta. Pada merek ada unsur ciptaan, misalnya design logo atau huruf. Ada hak cipta dalam bidang seni, namun dalam hak merek bukan hak cipta dalam bidang seni yang dilindungi tetapi mereknya itu sendiri dan hak merek itu terbatas hanya pada penggunaan atau pemakaiannya pada produk-produk yang dipasarkan dan mengandung nilai ekonomis. ${ }^{1}$ Merek bagi produsen merupakan citra sekaligus nama baik bagi perusahaan, selain itu juga merupakan bagian dari stategi bisnis. Tidak ada seorang produsen yang tidak menggunakan merek sebagai identitas atas barang yang diproduksinya atau jasa yang diberikan. Identitas yang diwujudkan dalam merek tersebut merupakan pengenal dan sekaligus pembeda antara merek suatu perusahaan tertentu dengan merek perusahaan yang lainnya.

Hak atas merek adalah hak yang bersifat khusus (exclusive) yang diberikan oleh negara kepada pemiliknya untuk menggunakan sendiri merek tersebut atau memberikan izin pada orang lain untuk menggunakannya. Pemberian hak khusus oleh negara tersebut, membawa konsekuensi bahwa untuk mendapatkannya harus melalui mekanisme pendaftaran, sehingga sifat pendaftaran adalah wajib (compulsory). Agar hak merek tersebut mendapat perlindungan dan pengakuan dari negara, maka pemilik merek harus mendaftarkannya pada negara. Jika suatu merek tidak didaftarkan, maka merek tersebut tidak akan dilindungi oleh negara. Konsekuensinya merek tersebut dapat digunakan oleh setiap orang. ${ }^{2}$ Perbedaan artikel ini dibandingkan dengan penelitian sebelumnya adalah artikel ini mengkaji dan menganalis bagaimana perlindungan pendaftaran merek dapat berakhir dan bagaimana perlindungan terhadap merek terdaftar. Hal apa saja yang bisa menyebabkan perlindungan merek terdaftar dapat berakhir yang sesuai dengan Undang-Undang No 20 Tahun 2016 Tentang Merek dan Indikasi Geografis. Selama ini penelitian yang ada hanya fokus pada pendaftaran merek, perlindungan merek, dan sengketa merek. Bahkan beberapa penelitian sebelumnya masih mengkaji dengan menggunakan Undang-Undang No 15 Tahun 2001 Tentang Merek.

Sekarang ini dalam strategi bisnis tidak lagi memecahkan persoalan tentang bagaimana memasarkan suatu produk barang atau jasa dengan baik atau

\footnotetext{
${ }^{1}$ Sulastri, Satino, Yuliana Yuli W, "Perlindungan Hukum Terhadap Merek (Tinjauan Terhadap Merek Dagang Tupperware Versus Tulipware)”, Jurnal Yuridis Vol. 5 No. 1 Juni 2018, Fakultas Hukum Universitas Pembangunan Nasional "Veteran" Jakarta, 2018, Jakarta, hal 162.

${ }^{2}$ Agung Sujatmiko, "Tinjauan Filosofis Perlindungan Hak Milik Atas Merek", Jurnal Media Hukum Vol 18 No 2 Desember 2011, Fakultas Hukum Universitas Muhammadiyah Yogyakarta, 2011, Yogyakarta, hal 177.
} 
menentukan kualitas yang memiliki standar yang tepat, tetapi juga bagaimana suatu merek barang atau jasa dapat diproteksi dari kompetitor lainnya. Oleh karena itu kompetisi dalam bisnis tidak hanya berupaya bagaimana merebut konsumen, tetapi juga berkompetisi untuk segera mengajukan pendaftaran merek atas setiap produk barang atau jasa. Merek dengan nama yang menarik, mudah dikenal dan diingat tentunya sangat diminati oleh para produsen agar produk barang/jasa miliknya juga mudah diingat dan dikenali oleh konsumen.

Sebagai isu internasional, merek berkembang dengan pesat. Bahkan, merek dari masyarakat cenderung dijadikan pembicaraan terus-menerus, baik ditingkat nasional maupun internasional. Sayangnya pelanggaran merek masih saja terus terjadi. Oleh karena itu, harus disadari oleh kita semua bahwa merek merupakan kreasi olah pikir manusia yang perlu diberi perlindungan hukum. ${ }^{3}$ Perkembangan dalam dunia bisnis yang menyangkut masalah merek seperti tersebut diatas, hal tersebut sebenarnya sangat memerlukan perhatian besar dari pemerintah untuk memberikan perlindungan hukum. Salah satu wujud perlindungan hukum yang dapat diberikan adalah pengaturan yang memadai tentang merek. Wujud lain perlindungan hukum dapat juga diperoleh dalam proses penegakan hukum. Jaminan yuridis juga bisa diberikan untuk mencegah terjadinya pelanggaran-pelanggaran terhadap hak atas merek milik perusahaan yang telah dimintakan pendaftaran.

Pelanggaran terhadap merek terdaftar tidak hanya dilakukan dengan modus memalsukan barang yang menyerupai aslinya baik itu barang/jasa melainkan juga terhadap nama merek terdaftar. Sebagai contoh pemalsuan baju merek "Hammer" dilakukan dengan membuta baju dan merek persis dengan produk asli milik "Hammer". Sekarang ini pelanggaran merek lebih kepada pemboncengan merek atau pemboncengan reputasi, modus ini dilakukan dengan membuat produk barang/jasa yang menyerupai merek terdafta aslinya sehingga konsumen atau masyarakat dapat terkecoh akibat tindakan pemboncengan ini. Perbuatan ini tidak hanya merugikan masyarakat dan konsumen tetapi juga merugikan produsen asli nerek terdaftar tersebut.

"Dalam sistem hukum common law, pemboncengan merek (passing off) ini merupakan suatu tindakan persaingan curang (unfair competition), dikarenakan tindakan ini mengakibatkan pihak lain selaku pemilik merek yang telah mendaftarkan mereknya dengan itikad baik mengalami kerugian dengan adanya pihak yang secara curang membonceng atau mendompleng merek miliknya untuk mendapatkan keuntungan finansial". 4

\footnotetext{
${ }^{3}$ Sudaryat, Sudjana, Rika Ratna Permata, "Hak Kekayaan Intelektual, Memahami Prinsip Dasar, Cakupan, Dan Undang-undang Yang Berlaku”, Oase Media, 2010, Bandung, hal 5.

${ }^{4}$ Nur Hidayati, "Perlindungan Hukum Pada Merek Yang Terdaftar", Ragam Jurnal Pengembangan Humaniora Vol. 11 No 3 Desember 2011, Politeknik Negeri Semarang, 2011, Semarang, hal 180.
} 
Bagi merek yang sudah didaftarkan oleh pemiliknya, itu saja masih bisa ditiru oleh orang lain apalagi jika merek itu belum didaftarkan. Sehingga apabila ada merek yang sudah terdaftar kemudian muncul merek baru yang mempunyai persamaan pada pokoknya atau keseluruhan dengan merek yang sudah terdaftar, kadang-kadang merek yang baru itupun juga terdaftar resmi di Direktorat Jenderal Kekayaan Inteletual (DJKI). Jika terjadi hal yang demikian kemudian pemilik merek yang pertama mengetahui, dia dapat mengajukan gugatan kepada Direktorat Jenderal Kekayaan Intelektual bahwa merek yang baru muncul itu mempunyai persamaan dengan mereknya. Apabila hal itu memang terbukti biasanya perlindungan terhadap hak atas merek terdaftar yang terakhir akan berakhir. Hal tersbut yang mendasari penelitian ini berjudul "Perlindungan Hukum Terhadap Merek Terdaftar".

\section{B. Perumusan Masalah}

Mengingat begitu luasnya masalah mengenai merek, maka dalam penelitian ini hanya membatasi mengenai berakhirnya perlindungan hukum terhadap hak atas merek terdaftar..

1. Mengapa perlindungan hukum terhadap hak atas merek terdaftar dapat berakhir?

2. Bagaimana upaya perlindungan hukum yang dapat diberikan terhadap merek terdaftar ?

\section{Metodelogi Penelitian}

Metode penelitian yang dipakai adalah yuridis normatif, yaitu suatu cara pendekatan terhadap masalah-masalah yang akan diteliti dengan cara meninjau dari segi perundang-undangan yang berlaku, serta melihat yang sesungguhnya yang terdapat dalam praktek atas kenyataan.

Sifat penelitian ini sesuai dengan masalah yang diajukan dipergunakan penelitian yang bersifat deskriptif analistis, yaitu penelitian yang menggambarkan atau melukiskan secara sistematis faktual dan akurat mengenai fakta-fakta tertentu tentang masalah-masalah yang akan diteliti.

Sumber data yang dipergunakan dalam penelitian ini :

1. Sumber data utama, yaitu data sekunder, dimana data ini diperoleh dari penelitian kepustakaan dan didukung atau dilengkapi dengan data-data yang diperoleh dari penelitian lapangan.

2. Sumber data pendukung adalah data primer, yaitu data yang diperoleh dari penelitian lapangan.

\section{PEMBAHASAN}

\section{A. Perlindungan Hukum Hak Atas Merek Terdaftar Berakhir}

Merek mempunyai fungsi untuk memberi tanda pengenal barang, guna membedakan barang seseorang atau perusahaan dengan barang orang atau perusahaan lain. Disamping itu ada tujuan-tujuan lain dilihat dari pihak 
produsen, pedagang dan konsumen. Dari pihak produsen, merek digunakan untuk jaminan nilai hasil produksi, khususnya mengenai kualitas, kemudahan pemakaiannya atau hal-hal yang pada umumnya berkenaan dengan teknologinya. Bagi pedagang, merek digunakan untuk mempromosikan barangbarang dagangannya guna mencari meluaskan pasaran. Dari pihak konsumen, merek diperlukan untuk mengadakan pilihan terhadap barang yang akan dibeli. ${ }^{5}$

Pengertian dan makna merek itu sendiri terus mengalami perkembangan jaman dengan menyesuaikan era globalisasi dan semakin berkembangnya teknologi. Pengertian merek menurut Undang-undang No 20 Tahun 2016 tentang Merek dan Indikasi Geografis, merek adalah tanda yang dapat ditampilkan secara grafis berupa gambar, logo, nama, kata, huruf, angka, susunan warna, dalam bentuk 2 (dua) dimensi dan/ atau 3 \{tiga) dimensi, suara, hologram, atau kombinasi dari 2 (dua) atau lebih unsur tersebut untuk membedakan barang dan atau jasa yang diproduksi oleh orang atau badan hukum dalam kegiatan perdagangan barang dan atau jasa.

Sedangkan pengertian merek menurut Undang-undang No 15 Tahun 2001, merek adalah Tanda yang berupa gambar, nama, kata, huruf-huruf, angka-angka, susunan warna, atau kombinasi dari unsur tersebut, yang memiliki daya pembeda dan digunakan dalam kegiatan perdagangan barang atau jasa. Adanya perubahan dari istilah merek menurut undang-undang sebagai salah satu upaya dari para pembuat undang-undang dalam mengantisipasi perkembangan teknologi yang semakin cepat. Era 4.0 ini teknologi dimanfaatkan untuk menciptakan dan mengembangkan merek.

Bagaimana sekarang produsen gawai memanfaatkan teknologi dalam menciptakan dan mengembangkan merek gawai melalui inovasi dan teknologi dalam menampilkan merek di gawai buatan mereka sebagai sarana dan tanda pengenal produk mereka di masyarakat. Bagaimana Samsung menciptakan suara, susunan warna dan hologram sebagai tanda pengenal di gawai produksi Samsung. Sebelumnya Nokia terlebih dahulu memperkenalkan susanan nada dan suara sebagai tanda pengenal pada gawai sebahai ciri khas dan pembeda produk dari Nokia. Merek sebagai hasil dari inovasi dan pengembangan teknologi juga perlu perlindugan hukum agar hasil dari karya mereka tidak ditiru di kemudian hari.

Era 4.0 ini, dengan perkembangan industri dan perdagangan, peranan tanda pengenal berkaitan dengan hasil industri dan barang dagangan makin menjadi penting. Sebagai akibat diberikannya tanda pengenal atas barangbarang hasil pekerjaannya itu, timbul cara yang mudah untuk memasarkan

\footnotetext{
${ }^{5}$ Ahmadi Miru, "Hukum Merek : Cara Mudah Mempelajari Undang-undang Merek”, PT. Raja Grafindo Persada, 2005, Jakarta, hal. 5.
} 
barang-barangnya. Merek merupakan suatu tanda pengenal dalam kegiatan perdagangan barang atau jasa yang sejenis dan sekaligus merupakan jaminan mutunya bila dibandingkan dengan produk barang atau jasa sejenis yang dibuat pihak lain. Merek tersebut bisa merek dagang atau bisa juga merek jasa. Merek dagang diperuntukkan sebagai pembeda bagi barang-barang yang sejenis yang dibuat perusahaan lain, sedangkan merek jasa diperuntukkan sebagai pembeda pada perdagangan jasa yang sejenis. Seseorang dengan melihat, membaca atau mendengar suatu merek, seseorang sudah dapat mengetahui secara persis bentuk dan kualitas suatu barang atau jasa yang akan diperdagangakan oleh pembuatnya.

Pengaturan perlindungan merek di Indonesia sudah ada sejak jaman Belanda yaitu dengan berlakunya Reglemen Industriele Eigendom (RIE) sesuai dengan Staatblad 1912 Nomor 545 jo Staatblad 1913 Nomor 214. Setelah memasuki masa penjajahan Jepang lahir pearturan yang mengatur tentang merek yang disebut Osamu Seire Nomor 30 tentang Pendaftaran Cap Dagang. UndangUndang Nomor 21 Tahun 1961 tentang Merek Perusahaan dan Merek Perniagaan, undang undang itu diterbitkan dalam upaya pemerintah untuk melindungi masyarakat dari barang bajakan dan tiruan. Selanjutnya pada tanggal 10 Mei 1979 Indonesia meratifikasi Konvensi Paris, Paris Convention for the Protection of Industrial Property (Stockholm Revision 1967) sesuai dengan Keputusan Presiden No. 24 Tahun 1979.

Karena Undang-Undang Nomor 21 Tahun 1961 tentang Merek Perusahaan dan Merek Perniagaan dianggap sudah tidak sesuai dengan perkembangan jaman pada saat itu, pemerintah pada tanggal 28 Agustus 1992 mengesahkan UU No. 19 tahun 1992 tentang Merek (UU Merek 1992), yang mulai berlaku tanggal 1 April 1993. Selanjutnya pada tanggal 15 April 1994 Pemerintah RI menandatangani Final Act Embodying the Result of the Uruguay Round of Multilateral Trade Negotiations, yang mencakup Agreement on Trade Related Aspects of Intellectual Property Rights (Persetujuan TRIPS).

Pendaftaran merek bertujuan untuk memperoleh kepastian hukum dan perlindungan hukum terhadap hak atas merek. Pendaftaran merek dilakukan pada Direktorat Jenderal Hak Kekayaan Intelektual. Direktorat Jenderal HKI adalah instansi pendaftaran merek yang ditugaskan untuk mendaftarkan merek yang dimohonkan pendaftarannya oleh pemilik merek. ${ }^{6}$ Sekarang ini Direktorat Jenderal Hak Atas Kekayaan Intelektual telah berubah penyebutannya menjadi Direktorat Jenderal Kekayaan Intelektual atau disingkat dengan DJKI.

Dikenal 2 (dua) macam sistem pendaftaran merek, yaitu sistem konstitutif dan sistem deklaratif. Sistem konstitutif, hak atas merek diperoleh melalui

\footnotetext{
${ }^{6}$ Syahriyah Semaun, "Perlindungan Hukum Terhadap Merek Perdagangan Barang Dan Jasa”, Jurnal Hukum Diktum Vol 14 No 1, Sekolah Tinggi Agama Islam Negeri Pare Pare, 2016, Pare Pare, hal 109-110.
} 
pendaftaran, artinya hak eksklusif atas sesuatu merek diberikan karena adanya pendaftaran. Sistem konstitutif, pendaftaran merek merupakan hal yang mutlak dilakukan. Merek yang tidak didaftar otomatis tidak akan mendapatkan perlindungan hukum.

Dengan sistem konstitutif ini, yang berhak atas suatu merek adalah pihak yang telah mendaftarkan mereknya. Pendaftaran itu menciptakan suatu hak atas merek tersebut, pihak yang mendaftarkan, dialah satu-satunya yang berhak atas suatu merek dan pihak ketiga harus menghormati haknya pendaftar sebagai hak mutlak. ${ }^{7}$ Sistem ini mengaharuskan para pemilik merek untuk mendaftarkan merek nya jika ingin mendapatkan perlindungan hukum atas merek. Penggunaan sistem konstitutif ini lebih melindungi pemilik merek dan menjamin kepastian hukum.

Sistem deklaratif yang mendasarkan pada perlindungan hukum bagi Mereka yang menggunakan Merek terlebih dahulu, selain kurang menjamin kepastian hukum juga menimbulkan persoalan dan hambatan dalam dunia usaha. Seperti dikatakan bahwa, perlindungan Merek terdaftar mutlak diberikan oleh pemerintah kepada pemegang dan pemakai hak atas Merek untuk menjamin terhadap kepastian berusaha bagi produsen. ${ }^{8}$

Adanya perubahan sistem pendaftaran yang dianut oleh Indonesia dari semula menganut sistem deklaratif menjadi sistem konstitutif yang mulai diterapkan dengan berlakunya Undang Nomor 19 Tahun 1992 tentang Merek, dinilai lebih mempunyai kepastian hukum. Merek yang sudah didaftarkan akan mempunyai perlindungan hukum sejak tanggal penerimaan pendaftaran merek.

Konsekuensi dari merek yang telah didaftar adalah harus dipergunakan dengan permintaan pendaftarannya. Undang Undang Merek menghendaki pemilik merek bersikap jujur dalam menggunakan mereknya, artinya merek yang telah didaftar dipergunakan sesuai kelas barang atau jasa yang didaftarkan juga harus sama bentuknya dengan merek yang dipergunakan. Apabila merek yang telah didaftarkan tidak dipergunakan sesuai dengan ketentuan yang ditetapkan dalam undang-undang, akan mengakibatkan pendaftaran merek yang bersangkutan dihapuskan. ${ }^{9}$

Pengaturan pendaftaran merek itu sendiri diatur dalam pasal 20, 21 dan 22 Undang-Undang No 20 Tentang Merek dan Indikasi Geografis. Suatu merek tidak boleh bertentangan dengan ideologi negara, peraturan perundangundangan, moralitas, agama, kesusilaan, ketertiban umum, memiliki kesamaan

\footnotetext{
${ }^{7}$ Saidin, Aspek Hukum Hak Kekayaan Intelektual (Intelektual Property Right), PT. Raja Grafindo Persada, 1995, Jakarta, hal. 175.

${ }^{8}$ Hery Firmansyah, "Perlindungan Hukum Terhadap Merek", Panduan Memahami Dasar Hukum Penggunaan Dan Perlindungan Merek, Pustaka Yustisia, 2011, Yogyakarta, hal. 38.

${ }^{9}$ Jisia Mamahit, "Perlindungan Hukum Atas Merek Dalam Perdagangan Barang Dan Jasa”, Jurnal Lex Privatum Vol I No.3, Universitas Sam Ratulangi, 2013, Manado, hal 92.
} 
pada keseluruhannya dengan ekspresi budaya tradisional, warisan budaya tak benda, atau nama atau logo yang sudah merupakan tradisi turun temurun.

Selain itu, terdapat pula merek kolektif yaitu merek yang digunakan pada barang dan atau jasa dengan karakteristik yang sama mengenai sifat, ciri umum, dan mutu barang atau jasa serta pengawasannya yang diperdagangkan oleh beberapa orang atau badan hukum secara bersama-sama untuk membedakan dengan barang dan atau jasa sejenis lainnya. ${ }^{10}$ Menurut Pasal 46 UndangUndang No 20 Tahun 2016 Tentang Merek dan Indikasi Geografis, permohonan pendaftaran merek sebagai merek kolektif hanya dapat diterima jika dalam permohonan dengan jelas dinyatakan bahwa merek tersebut akan digunakan sebagai merek kolektif.

Pada kenyataannya di lapangan, rendahnya pengetahuan mengenai perlindungan merek sangat mempengaruhi pula rendahnya upaya pendaftaran merek, khusunya bagi pemilik merek pada usaha UMKM (Usaha Mikro, Kecil, dan Menengah). Padahal produk yang dihasilkan tidak kalah kreatif dan inovatif dengan produk lain yang sejenis, bahkan dengan produk impor dari negaranegara lain. Namun, ada pula pelaku usaha yang sudah mengetahui fungsi tersebut, namun tidak mengetahui mekanisme untuk memperoleh perlindungan hak atas merek. Alasan keterbatasan biayapun menjadi salah satu pertimbangan belum dilakukannya pendaftaran merek, karena pada dasarnya, UMKM masih bersifat merintis usaha. Padahal, kelalaian seseorang dalam mendaftarakan suatu merek, dapat berakibat diklaim/didahului oleh pihak lain dalam mendaftarkan merek yang sama atau mirip untuk produk barang atau jasa sejenis, sehingga seseorang dapat kehilangan hak untuk menggunakan mereknya sendiri yang sebenarnya sudah lebih dahulu dipergunakan. ${ }^{11}$ Pelaksanaan pendaftaran merek kolektif adalah sebagai perhatian dari pemerintah untuk pemberdayaan Usaha Mikro, Kecil dan Menengah (UMKM) dalam upayanya melakukan pengembangan usaha. Sehingga akan memudahkan UMKM dalam melakasanakan pendaftaran merek kolektif sebinggga merek tersebut mempunyai perlindungan hukum.

Merek mempunyai masa berlaku selama 10 (sepuluh) tahun sejak tanggal penerimaan dan dapat diperpanjang lagi dengtan jangka waktu yang sama 10 (sepuluh) tahun. Proses perpanjangan merek dapat dilakukan langsung oleh pemilik merek atau kuasanya baik melalui elektronik maupun non elektronik. Proses perpanjangan dapat dilakukan 6 (enam) bulan sebelum berakhirnya masa berlakunya merek, dan 6 (enam) bulan sejak masa berlakunya merek habis

${ }^{10}$ Pasal 1 angka 4 Undang-Undang No.20 Tahun 2016 tentang Merek dan Indikasi Geografis.

${ }^{11}$ Yudhitiya Dyah Sukmadewi, "Pendaftaran Merek Asosiasi Sebagai Merek Kolektif (Kajian Terhadap Asosiasi Rajut Indonesia Wilayah Jawa Tengah)", Jurnal Ius Constituendum Vol 2 No 1 April 2017, Magister Hukum Universitas Semarang, Semarang, 2017, Semarang, hal 110. DOI : 10.26623/jic.v2i1.547 
dengan membayar denda yang telah ditetapkan. Pengaturan mengenai perpanjangan merek diatur dalam Pasal 35, 36, 37, 38, 39 dan 40 UndangUndang No 20 Tahun 2016 Tentang Merek dan Indikasi Geografis.

Adapun yang menjadi syarat dalam proses perpanjangan merek sebagaimana diatur dalam Pasal 36 Undang-Undang No 20 Tahun 2016 adalah bahwa merek harus dipergunakan sebagaimana tercantum dalam sertifikat merek, artinya penggunaan merek barang/jasa harus sesuai dengan sertifikat dalam merek. Sebagai contoh kecap merek "Merak" harus sesuai dengan tercantum dalam sertifikat merek yaitu kecap dengan merek "Merak". Jika yang ditemukan adalah saos merek "Merak", maka ini melanggar sertifikat merek dan merek dapat dihapuskan atau tidak dapat diperpanjang. Yang menjadi syarat selanjutnya adalah bahwa barang/jasa dengan merek yang terdaftar masih diproduksi dan atau diperdagangkan. Jika barang/jasa tersebut pada kenyataannya sudah berhenti produksi dan tidak diperdagangkan lagi maka merek tersebut tidak dapat diperpanjang.

Pendaftaran merek mempunyai masa berlakunya yaitu selama 10 (sepuluh ) tahun dan dapat diperpanjang lagi dengan jangka waktu yang sama. Berakhirnya masa berlakunya pendaftaran merek otomatis berakhir pula perlindungan hukum terhadap merek tersebut. ${ }^{12}$

Merek yang bersangkutan masih digunakan pada barang atau jasa sebagaimana dicantumkan dalam sertifikat merek tersebut; dan b. barang atau jasa sebagaimana dimaksud dalam huruf a masih diproduksi dan atau diperdagangkan. ${ }^{13}$ Merek disamping akan dihapus pendaftarannya karena habis masa berlakunya, penghapusan merek terdaftar juga dapat dilakukan karena atas kemauan pemilik merek itu sendiri. Proses penghapusan merek terdaftar atas inisiatif pemilik merek yaitu dengan melakukan permohonan kepada Menteri Hukum dan Hak Asasi Manusia sebagaimana diatur dalam pasal 72 ayat 1 dan 2 Undang-Undang No 20 Tahun 2016.

Penghapusan suatu merek terdaftar juga dapat dilakukan atas prakarsa Menteri Hukum dan Hak Asasi Manusia. Penghapusan atas merek terdaftar atas prakarsa Menteri dapat dilakukan jika a. memiliki persamaan pada pokoknya danyatau keseluruhannya dengan Indikasi Geografis; b. bertentangan dengan ideologi negara, peraturan perundang-undangan, moralitas, agama, kesusilaan, dan ketertiban umum; atau c. memiliki kesamaan pada keseluruhannya dengan ekspresi budaya tradisional, warisan budaya tak benda, atau nama atau logo yang sudah merupakan tradisi turun temurun. ${ }^{14}$ Penghapusan atas prakarsa Menteri dapat dilakukan setelah mendapatkan rekomendasi dari Komisi

\footnotetext{
${ }^{12}$ Pasal 35 Undang-Undang No.20 Tahun 2016 tentang Merek dan Indikasi Geografis.

${ }^{13}$ Pasal 36 Undang-Undang No.20 Tahun 2016 tentang Merek dan Indikasi Geografis.

${ }^{14}$ Pasal 72 ayat 6 dan 7 Undang-Undang No.20 Tahun 2016 tentang Merek dan Indikasi Geografis.
} 
Banding Merek. Jika pemilik merek terdaftar keberatan atas keputusan penghapusan oleh Menteri, dapat melakukan gugatan ke Pengadilan Tata Usaha Negara (PTUN).

Penghapusan Merek terdaftar dapat pula diajukan oleh pihak ketiga yang berkepentingan dalam bentuk gugatan ke Pengadilan Niaga dengan alasan Merek tersebut tidak digunakan selama 3 (tiga) tahun berturut-turut dalam perdagangan barang dan/atau jasa sejak tanggal pendaftaran atau pemakaian terakhir. $^{15}$

Berdasarkan pasal-pasal tersebut diatas, terdapat 4 (empat) hal yang mengakibatkan berakhirnya perlindungan hukum atas merek terdaftar yaitu : berakhirnya masa berlakunya pendaftaran merek, penghapusan merek terdaftar atas inisiatif pemilik merek, penghapusan merek atas prakarsa menteri dan adanya gugatan dari pihak ketiga.

\section{B. Perlindungan Hukum Hak Atas Merek Terdaftar}

Perkembangan di bidang perdagangan dan industri yang sedemikian pesatnya memerlukan peningkatan perlindungan terhadap teknologi yang digunakan dalam proses pembuatan, apabila kemudian produk tersebut beredar di pasar dengan menggunakan merek tertentu, maka kebutuhan untuk melindungi produk yang dipasarkan dari berbagai tindakan melawan hukum pada akhirnya merupakan kebutuhan untuk melindungi merek tersebut. ${ }^{16}$

Perlindungan hukum yang diberikan oleh negara terhadap hak atas merek meliputi perlindungan merek dalam negeri maupun merek luar negeri sebagaimana tersebut dalam prinsip timbal balik, dimana setiap anggota wajib memberikan perlindungan yang sama terhadap kekayaan intelektual warga anggota lain seperti perlindungan yang diberikan kepada anggotanya sendiri.

Secara historis, peraturan perundang-undangan di bidang HKI di Indonesia telah ada sejak tahun 1840-an. Pemerintah Kolonial Belanda memperkenalkan undang-undang pertama mengenai perlindungan HKI pada tahun 1844. Selanjutnya, Pemerintah Belanda mengundangkan UU Merek (1885), UU Paten (1910), dan UU Hak Cipta (1912). Indonesia yang pada waktu itu masih bernama Netherlands East-Indies telah menjadi anggota Paris Convention for the Protection of Industrial Property sejak tahun 1888 dan anggota Berne Convention for the Protection of Literary and Aristic Works sejak tahun 1914. Pada jaman pendudukan Jepang yaitu tahun 1942 s.d. 1945, semua peraturan perundang-undangan di bidang HKI tersebut tetap berlaku. ${ }^{17}$

\footnotetext{
${ }^{15}$ Pasal 74 Undang-Undang No.20 Tahun 2016 tentang Merek dan Indikasi Geografis.

${ }^{16}$ Nourma Dewi, Tunjung Baskoro, "Kasus Sengketa Merek Prada S.A Dengan PT. Manggala Putra Perkasa Dalam Hukum Perdata Internasional”, Jurnal Ius Constituendum Vol 4 No 1 April 2019, Magister Hukum Universitas Semarang, 2019, Semarang, hal 20. DOI : 10.26623/jic.v4i1.1531

${ }^{17} \mathrm{https}$ ://dgip.go.id/sejarah-perkembangan-perlindungan-kekayaan-intelektual-ki, diunduh tanggal 20 Januari 2020 pukul 11.20 WIB.
} 
Pengaturan merek di Indonesia dimulai dengan adanya Undang-Undang Nomor 21 Tahun 1961 kemudian diubah dengan Undang-Undang Nomor 12 Tahun 1992, dan kemudian diubah lagi dengan Undang-Undang Nomor 15 Tahun 2001 tentang Merek dan terakhir Undang-Undang No 20 Tahun 2016 tentang Merek dan Indikasi Geografis, hal ini menunjukan bahwa peranan dan upaya untuk perlindungan merek sangat penting.

Telah diaturnya syarat-syarat yang harus dipenuhi oleh si pemohon dalam mengajukan permohonan pendaftaran merek tidak menghilangkan sama sekali terjadinya pelanggaran merek oleh pihak yang tidak bertanggung jawab. Penggunaan secara tanpa hak atas merek pada suatu produk dengan maksud mengambil keuntungan atas merek yang digunakannya masih banyak terjadi dalam berbagai bentuk, misalanya pembajakan (merek dipalsu) atau melalui pemanfaatan reputasi (terjadi persamaan pada pokoknya pada merek yang mempunyai reputasi dimata konsumen).$^{18}$

Perlindungan hukum yang diberikan oleh negara juga tidak hanya terbatas pada pemilik merek, tetapi juga kepada konsumen yang menginginkan aman, nyaman dan terjamin dalam mendapatkan merek yang asli sehingga tidak terkecoh dalam membeli barang dengan merek palsu. Perlindungan hukum yang diberikan kepada pemilik merek adalah pemilik merek yang mempunyai iktikad baik, artinya sekalipun telah mempunyai sertifikat sebagai bukti kepemilikan suatu merek, namun dapat dimintakan penghapusan atau pembatalan atas merek tersebut jika pemiliknya terbukti mempunyai iktikad buruk.

Perlindungan hukum terhadap merek hanya diberlakukan terhadap merek yang telah didaftarkan. Pendaftaran merek akan memberikan pelindungan yang lebih kuat, khususnya jika bertentangan dengan merek yang identik atau yang mirip. Walaupun sebagian besar pelaku bisnis menyadari pentingnya penggunaan merek untuk membedakan produk yang dimiliki dengan produk para pesaingnya, namun tidak semua pihak menyadari mengenai pentingnya pelindungan merek melalui pendaftaran. ${ }^{19}$

Adanya perlindungan tersebut menunjukkan bahwa negara berkewajiban dalam menegakkan hukum Merek. Oleh karena itu apabila ada pelanggaran terdaftar, pemilik Merek dapat mengajukan gugatan ke Pengadilan yang berwenang. Dengan perlindungan tersebut maka akan terwujud keadilan yang menjadi tujuan dari hukum. Salah satu tujuan hukum adalah mewujudkan

\footnotetext{
${ }^{18}$ Fajar Nurcahya Dwi Putra, "Perlindungan Hukum Bagi Pemegang Hak Atas Merek Terhadap Perbuatan Pelanggaran Merek", Mimbar Keadilan, Jurnal Ilmu Hukum, Edisi: Januari-Juni 2014, Fakultas Hukum Universitas 17 Agustus 1945 Surabaya, 2014, Surabaya hal. 98-99.

${ }^{19}$ Tommy Hendra Purwaka, "Perlindungan Merek", (Cetakan Pertama) Yayasan Pustaka Obor Indonesia, 2017, Jakarta, hal 39-40.
} 
keadilan masyarakat. Dengan perlindungan hukum maka pemilik merek yang sah terlindungi hak-haknya. ${ }^{20}$

Menurut Pasal 2 ayat 3 Undang-Undang No 20 Tahun 2016, Merek yang dilindungi terdiri atas tanda berupa gambar, logo, nama, kata, huruf, angka, susunan warna, dalam bentuk 2 (dua) dimensi dan/ atau 3 (tiga) dimerisi, suara, hologram, atau kornbinasi dari 2 (dua) atau lebih unsur tersebut untuk membedakan barang dan atau jasa yang diproduksi oleh orang atau badan hukum dalam kegiatan perdagangan barang dan/atau jasa.

Permohonan pendaftaran akan ditolak jika merek tersebut mernpunyai persamaan pada pokoknya atau keseluruhannya dengan a. Merek terdaftar milik pihak lain atau dimohonkan lebih dahulu oleh pihak lain untuk barang dan Zatau jasa sejenis; b. Merek terkenal milik pihak lain untuk barang dari/atau jasa sejenis; c. Merek terkenal milik pihak lain untuk barang dan/atau jasa tidak sejenis yang memenuhi persyaratan tertentu. ${ }^{21}$

Hal lain yang sangat penting dalam pelindungan merek adalah bahwa merek tidak dapat didaftarkan atas dasar permohonan yang diajukan oleh pemohon yang beriktikad tidak baik. Ukuran iktikad baik ini menjadi ukuran yang sulit untuk diukur secara kasat mata, bahkan seringkali sengketa muncul karena niat buruk untuk mendaftarkan merek dengan ciri-ciri yang mirip atau bahkan sama dengan cara memalsukan merek dan desain bungkusnya. Oleh karena itu, pendaftaran dengan iktikad baik ini merupakan salah satu upaya melindungi merek terkenal. Lebih lanjut Undang-undang merek juga telah berupaya memberikan pelindungan bagi merek terkenal yang mengatur bahwa permohonan harus ditolak apabila: (a) mempunyai persamaan pada pokoknya atau keseluruhannya dengan merek pihak lain yang telah terdaftar lebih dahulu untuk barang atau jasa yang sejenis, (b) mempunyai persamaan pada pokoknya atau keseluruhannya dengan merek yang terkenal milik pihak lain atau barang dan/atau jasa yang sejenis. ${ }^{22}$

Pasal 35 UU No. 20 Tahun 2016 menyebutkan bahwa merek terdaftar mendapat perlindungan hukum untuk jangka waktu 10 (sepuluh) tahun sejak tanggal penerimaan dan jangka waktu pelindungan itu dapat diperpanjang dan dapat diperpanjang dengan jangka waktu yang sama. Pelaksanaan pendaftaran dan perpanjangan merek terdaftar dapat dilakukan secara eletronik dan non elektronik sebagai upaya dari pemerintah untuk mempermudah masyarakat dalam melakukan pendaftaran merek.

\footnotetext{
${ }^{20}$ Haryono, "Perlindungan Hukum Terhadap Merek Terdaftar", Jurnal Ilmiah CIVIS Vol II No 1 Januari 2012, Universitas PGRI Semarang, 2012, Semarang, hal. 241.

${ }^{21}$ Pasal 21 ayat 1 huruf a, b dan c Undang-Undang No.20 Tahun 2016 tentang Merek dan Indikasi Geografis.

${ }^{22}$ Edy Santoso, "Penegakan Hukum Terhadap Pelanggaran Merek Dagang Melalui Peran Kepabeanan Sebagai Upaya Menjaga Keamanan dan Kedaulatan Negara”, Jurnal Rechtsvinding Vol 5 No.1 April 2016, Badan Pembinaan Hukum Nasional, 2016, Jakarta, hal. 124.
} 
Ketidakjelasan menyebabkan putusan pengadilan beragam terhadap merek terkenal. Sengketa dan Konflik Merek Terkenal sangat banyak sekali ditemui di Indonesia. Hal ini dapat kita lihat pada beberapa kasus merek terkenal yang terjadi. Antara lain perkara dengan nomor putusan 384K/Pdt.Sus-HKI/2014, perkara antara Toyota sebagai pemilik merek Lexus melawan Ganda Christ Robert M sebagai pemilik merek Menara Lexus. Dalam perkara ini hakim agung memenangkan Toyota sebagai pemilik merek Lexus untuk kendaraan bermotor dan suku cadangnya karena Lexus adalah merek terkenal sesuai dengan UU Merek dan Lexus milik Toyota sudah terdaftar lebih dahulu yaitu sejak tahun 1992 dan terus diperpanjang perlindungannya hingga saat ini. ${ }^{23}$

Adanya perlindungan hukum adalah sebagai bentuk telah bekerjanya fungsi hukum yang harus memberikan keadilan, kemanfaatan dan kepastian hukum. Berlakunya perlindungan hukum atas merek terdaftar akan mendorong investasi dan meningkatkan kepercayaan investor dalam menjalankan usahanya di Indonesia. Jika perlindungan hukum atas mere terdaftar tidak berjalan maka minat investor dalam menananamkan modal dan menjalankan usahanya di Indonesia akan melemah, dan ini sangat tidak menguintungkan bagi perekonomian Indonesia.

Menurut Zen Umar Purba, alasan mengapa Hak Karya Inteletual (HKI) perlu dilindungi oleh hukum sebagai berikut: ${ }^{24}$

a. Alasan yang "bersifat non ekonomis", menyatakan bahwa pelindungan hukum akan memacu mereka yang menghasilkan karya-karya intelektual tersebut untuk terus melakukan kreativitas intelektual. Hal ini akan meningkatkan self actualization pada diri manusia. Bagi masyarakat hal ini akan berguna untuk meningkatkan perkembangan hidup mereka.

b. Alasan yang "bersifat ekonomis", adalah untuk melindungi mereka yang melahirkan karya intelektual tersebut berarti yang melahirkan karya tersebut mendapat keuntungan materiil dari karya-karyanya. Di lain pihak melindungi mereka dari adanya peniruan, pembajakan, penjiplakan maupun perbuatan curang lainnya yang dilakukan oleh orang lain atas karya-karya yang berhak.

Sedangkan menurut Philipus M. Hadjon, ${ }^{25}$ bahwa sarana pelindungan hukum ada 2 (dua) macam, yaitu : Pertama, Sarana Perlindungan Hukum Preventif. Pada perlindungan hukum preventif ini, subjek hukum diberikan kesempatan untuk mengajukan keberatan atau pendapatnya sebelum suatu keputusan pemerintah mendapat bentuk yang definitif. Tujuannya adalah mencegah terjadinya sengketa. Perlindungan hukum preventif sangat besar

\footnotetext{
${ }^{23}$ Rakhmita Desmayanti, "Tinjauan Umum Perlindungan Merek Terkenal Sebagai Daya Pembeda Menurut Prespektif Hukum Di Indonesia”, Jurnal Cahaya Keadilan Vol 6 No. 1 April 2018, Universitas Putera Batam, 2018, Batam, hal. 17. DOI: https://doi.org/10.33884/jck.v6i1.874

${ }^{24}$ A. Zen Umar Purba dalam Anne Gunawati, "Pelindungan Merek Terkenal Barang dan Jasa Tidak Sejenis Terhadap Persaingan Usaha Tidak Sehat”, PT. Alumni, 2015, Bandung, hal. 83. hal. 2.

${ }^{25}$ Philipus M. Hadjon, “Pelindungan Hukum Bagi Rakyat Indonesia”, PT. Bina Ilmu, 1987, Surabaya,
} 
artinya bagi tindakan pemerintah yang didasarkan pada kebebasan bertindak karena dengan adanya pelindungan hukum yang preventif pemerintah terdorong untuk bersifat hati-hati dalam mengambil keputusan yang didasarkan pada diskresi. Di Indonesia belum ada pengaturan khusus mengenai pelindungan hukum preventif. Kedua, Sarana Perlindungan Hukum yang Represif bertujuan untuk menyelesaikan sengketa. Penanganan pelindungan hukum oleh pengadilan umum dan pengadilan administrasi di Indonesia termasuk kategori pelindungan hukum ini. Prinsip perlindungan hukum terhadap tindakan pemerintah bertumpu dan bersumber dari konsep tentang pengakuan dan pelindungan terhadap hak-hak asasi manusia karena menurut sejarah dari barat, lahirnya konsep-konsep tentang pengakuan dan perlindungan terhadap hak-hak asasi manusia diarahkan kepada pembatasan-pembatasan dan peletakan kewajiban masyarakat dan pemerintah.

Adanya perbuatan passing off ini pemalsu memanfaatkan reputasi dan terkenalnya suatu merek, sehingga pemalsu tidak perlu lagi membangun dari awal image dan merek dari produksi itu sendiri, hal iini juga dapat mengakibatkan konsumen yang hendak membeli atau mempergunakan merek yang asli pada akhirnya membeli atau menggunakan merek yang hampir sama tersebut. Ini juga akan menimbulkan kebingungan masyarakat dan konsumen dalam menentukan merek yang sebenarnya. Akibat adanya passing off ini yang dirugikan tidak hanya konsumen tetapi juga produsen asli yang memproduksi barang/jasa atas nama merek terdaftar tersebut.

Perbuatan passing off ini melanggar Pasal 382 KUHP yang berbunyi "Barangsiapa untuk mendapatkan, melangsungkan atau memperluas hasil perdagangan atau perusahaan milik sendiri atau orang lain, melakukan perbuatan curang untuk menyesatkan khalayak umum atau seorang tertentu, diancam, jika perbuatan itu dapat menimbulkan kerugian bagi konkurenkonkurennya atau konkuren-konkuren orang lain karena persaingan curang, dengan pidana penjara paling lama satu tahun empat bulan atau pidana denda paling banyak tiga belas ribu lima ratus rupiah".

Selain itu, pelindungan hukum secara perdata juga diberikan kepada pemegang merek yang sah. Apabila hak merek telah dipegang, maka menurut sistem hukum merek Indonesia, pihak pemegang merek tersebut akan mendapatkan pelindungan hukum, artinya apabila terjadi pelanggaran hak atas merek, pihak pemegang merek dapat mengajukan gugatan terhadap pihak lainnya yang melakukan pelanggaran hak atas merek. Gugatan ini ditujukan untuk mendapatkan ganti rugi dan penghentian semua perbuatan yang berkaitan dengan penggunaan merek tersebut. Gugatan diajukan di pengadilan niaga dengan disertakan identitas pemohon secara lengkap. Begitu pula dengan identitas dan alamat kuasa pemohon, bila diwakilkan. Selain itu mencantumkan 
warna, bila permohonan menggunakan unsur warna. Begitu pun nama negara dan tanggal permintaan merek, serta uraian jenis produk barang atau jasa dan dilampiri label merek juga bukti pembayaran biaya. ${ }^{26}$

Salah satu contoh sengketa merek terjadi apada awal September 2015, PT Phapros yang merupakan perusahaan lokal berasal dari Semarang mengajukan permohonan kasasi melawan Merck KGaA yang merupakan perusahaan farmasi multinasional berasal dari Jerman dengan nomor permohonan 409 K/Pdt.SusHKI/2015. Kasus ini berawal pada Januari 2015, dimana Merck mengajukan gugatan kepada Pengadilan Niaga pada Pengadilan Niaga Jakarta Pusat dengan perkara No. 52/Pdt.Sus/MEREK/2014/PN.Niaga.Jkt.Pst. Pemilik Merck menilai bahwa PT Phapros telah menggunakan nama merek Bioneuron tanpa sepengetahuannya yang memiliki kesamaan bentuk, ucapan dan bunyi. Hal tersebut dianggap dapat membuat konsumen keliru dalam membedakan perusahaan pemilik merek yang bersangkutan. Berkaitan dengan hal ini, PT Phapros sebagai tergugat menganggap bahwa gugatan tersebut mengada-ada sehingga tidak dapat dibenarkan. Majelis Hakim dalam pengadilan tingkat pertama memutuskan bahwa pihak Merck sebagai penggugat dapat menguatkan dalil-dalilnya sehingga pada tingkat pertama, pihak Merck dimenangkan. Tidak terima dengan keputusan Majelis Hakim pada tingkat pertama, PT Phapros mengajukan permohonan kasasi karena merasa bahwa Majelis Hakim dalam pengadilan tingkat pertama terkesan memihak. Majelis hakim menolak permohonan kasasi tersebut dengan menyatakan bahwa majelis hakim pada pengadilan tingkat pertama tidak salah dalam menerapkan hukum. "Setelah meneliti secara saksama memori kasasi tanggal 29 Januari 2015 dan kontra memori kasasi tanggal 25 Februari 2015 dihubungkan dengan pertimbangan judex facti, dalam hal ini Pengadilan Niaga pada Pengadilan Negeri Jakarta Pusat tidak salah menerapkan hukum," demikian pernyataan majelis hakim pada putusan perkara nomor $409 \mathrm{~K} / \mathrm{Pdt}$. Sus-HKI/2015. ${ }^{27}$

Kasus sengketa antara Merck dengan PT. Phapros pada akhirnya mengabulkan gugatan dari Merck karena Bioneuron mempunyai persamaan pada pokoknya yaitu Bioneuron dibuat dengan dominasi warna biru dan putih serta bentuk dan logo menyerupai orang yang miliknya Merck, dan komposisi yang terkandung dalam Bioneuron sama persisi dengan milik Merck yang terdiri

\footnotetext{
${ }^{26}$ Fandi H. Kowel, "Pelindungan Hukum Terhadap Penerima Lisensi Merek Di Indonesia", Jurnal Lex et Societatis Vol V No. 3 Mei 2017, Fakultas Hukum Universitas Sam Ratulangi, 2017, Manado, hal. 55.

27 https://kliklegal.com/lima-kasus-merek-terkenal-di-pengadilan-indonesia/, diunduh pada tanggal 9 Maret 2020 jam 13.05 Wib.
} 
dari B1, Vitamin C6 dan Vitamin B12. Dikabulkannya gugatan tersebut oleh Mahkamah Agung maka merek Bioneuron dihapuskan dari daftar umum merek.

\section{PENUTUP}

Berakhirnya perlindungan hukum atas merek terdaftar ditinjau dari Undang-undang No. 20 Tahun 20016 Tentang Merek dan Indikasi Geografis dapat terjadi karena Merek yang telah terdaftar pada Direktorat Jenderal Kekayaan Inteletual tersebut dihapus dari daftar umum merek karena telah berakhirnya masa berlakunya pendaftaran merek, penghapusan merek karena permintaan sendiri dari pemilik merek, penghapusaan merek terdaftar atas prakarsa dari Menteri Hukum san Hak Asasi Manusia setelah mendapatkan rekomendasi dari Komisi Banding Merek, dan penghapusan merek karena adanya gugatan dari pihak ketiga. Perlindungan merek tidak hanya sebagai perlindungan negara terhadap mpemilik merek terdaftar tetapi juga bentuk perlindungan terhadap masyarakat selaku konsumen agar mendapatkan barang sesuai dengan aslinya dan keinginannya dalam mendapatkan kepastian hukum atas barang yang dibeli di masyarakat. Bentuk perlindungan merek antara lain dengan melakukan pendaftaran merek, perlindungan merek selama masa jangka waktu terdaftarnya merek selama 10 (sepuluh) tahun dan dapat diperpanjang dengan jangka waktu yang sama, adanya penindakan baik gugatan secara perdata, penuntutan secara pidana maupun langkah administratif berupa penolakan pendaftaran merek dan penghapusan merek.

Direktorat Jenderal Kekayaan Intelektual dapat segera menghapus merek dari daftar umum merek apabla telah memenuhi ketentuan merek tersebut telah memenuhi syarat dihapusnya dari daftar umum merek, dengan dihapusnya merek tersebut maka perlindungan atas merek berakhir. Pemilik merek yang terdaftar dan beriktikad baik agar mendapatjkan perlindungan hukum sesuai undang-undang, dan para pihak yang melakukan pelanggran terhadap merek terdaftar dikenai sanksi yang tegas sesuai aturan yang berlaku baik itu pidana maupun administrasi. 


\section{DAFTAR PUSTAKA}

\section{Buku}

Ahmadi Miru, “Hukum Merek : Cara Mudah Mempelajari Undang-Undang Merek", PT. Raja Grafindo Persada, 2005, Jakarta.

A. Zen Umar Purba dalam Anne Gunawati, "Perlindungan Merek Terkenal Barang dan Jasa Tidak Sejenis Terhadap Persaingan Usaha Tidak Sehat”, PT. Alumni, 2015, Bandung

Hery Firmansyah, "Perlindungan Hukum Terhadap Merek, Panduan Memahami Dasar Hukum Penggunaan Dan Perlindungan Merek", Pustaka Yustisia, 2011,Yogyakarta.

Philipus M. Hadjon, "Perlindungan Hukum Bagi Rakyat Indonesia”, PT. Bina Ilmu, 1987, Surabaya.

Saidin, “Aspek Hukum Hak Kekayaan Intelektual (Intelektual Property Right)”, PT. Raja Grafindo Persada, 1995, Jakarta.

Sudaryat, Sudjana, Rika Ratna Permata, "Hak Kekayaan Intelektual, Memahami Prinsip Dasar, Cakupan, Dan Undang-Undang Yang Berlaku”, Oase Media, 2010, Bandung.

Tommy Hendra Purwaka, "Perlindungan Merek", (Cetakan Pertama) Yayasan Pustaka Obor Indonesia, 2017, Jakarta.

\section{Jurnal}

Agung Sujatmiko, Tinjauan Filosofis Perlindungan Hak Milik Atas Merek, Jurnal Media Hukum Vol 18 No 2 Desember 2011, Fakultas Hukum Universitas Muhammadiyah Yogyakarta, 2011, Yogyakarta.

Edy Santoso, "Penegakan Hukum Terhadap Pelanggaran Merek Dagang Melalui Peran Kepabeanan Sebagai Upaya Menjaga Keamanan dan Kedaulatan Negara”, Jurnal Rechtsvinding Vol 5, No.1 April 2016, Badan Pembinaan Hukum Nasional, 2016, Jakarta.

Fajar Nur Cahya Dwiputra, "Perlindungan Hukum Bagi Pemegang Hak Atas Merek Terhadap Perbuatan Pelanggaran Merek", Mimbar Keadilan, Jurnal Ilmu Hukum, Edisi: Januari - Juni 2014, Fakultas Hukum Universitas 17 Agustus 1945 Surabaya, 2014, Surabaya.

Fandi H. Kowel, "Perlindungan Hukum Terhadap Penerima Lisensi Merek Di Indonesia", Jurnal Lex et Societatis Vol V No. 3 Mei 2017, Fakultas Hukum Universitas Sam Ratulangi, 2017, Manado.

Haryono, "Perlindungan Hukum Terhadap Merek Terdaftar", Jurnal Ilmiah CIVIS Vol II, No 1 Januari 2012, Universitas PGRI Semarang, 2012, Semarang.

Jisia Mamahit, "Perlindungan Hukum Atas Merek Dalam Perdagangan Barang Dan Jasa”, Jurnal Lex Privatum, Vol. I No.3, Universitas Sam Ratulangi, 2013, Manado.

Nourma Dewi, Tunjung Baskoro, "Kasus Sengketa Merek Prada S.A Dengan PT. Manggala Putra Perkasa Dalam Hukum Perdata Internasional", Jurnal Ius Constituendum Vol 4 No 1 April 2019, Magister Hukum Universitas Semarang, 2019, Semarang. 
DOI : $\underline{10.26623 / j i c . v 4 i 1.1531}$

Nur Hidayati, "Perlindungan Hukum Pada Merek Yang Terdaftar", Ragam Jurnal Pengembangan Humaniora Vol. 11 No 3 Desember 2011, Politeknik Negeri Semarang, 2011, Semarang.

Rakhmita Desmayanti, "Tinjauan Umum Perlindungan Merek Terkenal Sebagai Daya Pembeda Menurut Prespektif Hukum Di Indonesia", Jurnal Cahaya Keadilan Vol. 6. No. 1 April 2018, Universitas Putera Batam, 2018, Batam. DOI: https://doi.org/10.33884/jck.v6i1.874

Syahriyah Semaun, "Perlindungan Hukum Terhadap Merek Perdagangan Barang Dan Jasa”, Jurnal Hukum Diktum Vol 14 No 1, Sekolah Tinggi Agama Islam Negeri Pare Pare, 2016, Pare Pare. DOI https://doi.org/10.35905/diktum.v14i1

Sulastri, Satino, Yuliana Yuli W, Perlindungan Hukum Terhadap Merek (Tinjauan Terhadap Merek Dagang Tupperware Versus Tulipware) Jurnal Yuridis Vol. 5 No. 1 Juni 2018, Fakultas Hukum Universitas Pembangunan Nasional "Veteran" Jakarta, 2018, Jakarta

Yudhitiya Dyah Sukmadewi, "Pendaftaran Merek Asosiasi Sebagai Merek Kolektif (Kajian Terhadap Asosiasi Rajut Indonesia Wilayah Jawa Tengah), Jurnal Ius Constituendum Vol 2 No 1 April 2017, Magister Hukum Universitas Semarang, 2017, Semarang.

DOI : $10.26623 / j i c . v 2 i 1.547$

\section{Undang-Undang}

Undang-Undang No 15 Tahun 2001 Tentang Merek

Undang-Undang Nomor 20 Tahun 2016 Tentang Merek dan Indikasi Geografis

\section{Internet}

https://dgip.go.id/sejarah-perkembangan-perlindungan-kekayaan-intelektual-ki https://kliklegal.com/lima-kasus-merek-terkenal-di-pengadilan-indonesia/ 